\title{
Endothelial keratoplasty detachment secondary to herpes simplex dendritic ulcer
}

\author{
James Common 지, Shokufeh Tavassoli, Kieren Darcy
}

Department of Cornea, Bristol Eye Hospital, Bristol, UK

\section{Correspondence to Shokufeh Tavassoli; shokufeh_tavassoli@hotmail. com}

Accepted 14 May 2020

\section{DESCRIPTION}

A 77-year-old woman with advanced Fuchs' endothelial dystrophy underwent an uncomplicated phacoemulsification and intraocular lens implantation with Descemet membrane endothelial keratoplasty (DMEK) in her left eye. On day 1 the graft was attached but on day 10 at a routine follow-up the patient reported ongoing blurred vision in her left eye. Central graft detachment was noted on examination, and a rebubble procedure with air was successfully carried out. A week later the graft was attached.

One month after the original procedure the patient returned with symptom of a sore left eye. On examination there was a localised detachment of the DMEK graft and interestingly in the exact area overlying this there was a dendritic ulcer, there were no signs of rejection with the rest of the graft remaining attached and clear (figures 1 and 2). There was no known ocular history of herpetic eye disease or any history of immunosuppression (asides from diet controlled type 2 diabetes mellitus). The occurrence of herpes simplex virus keratitis (HSVK) had resulted in localised graft detachment. Treatment for HSVK was started with aciclovir eye ointment five times per day and higher dose $1 \mathrm{~g}$ oral valaciclovir three times per day. The HSVK responded well so after 25 days the regime was reduced to a maintenance higher dose of oral valacivlovir $1 \mathrm{~g}$ once a day.

The HSVK induced graft detachment led to graft failure. Once the HSVK had cleared, a redo DMEK was performed 7 months after the initial DMEK. Treatment dose oral valaciclovir $1 \mathrm{~g}$ three times per day was initiated a week prior to the procedure and continued for a month afterwards before being reduced to a prophylactic dose. There was excellent visual recovery and graft survival with no further recurrence of HSVK. At follow-up

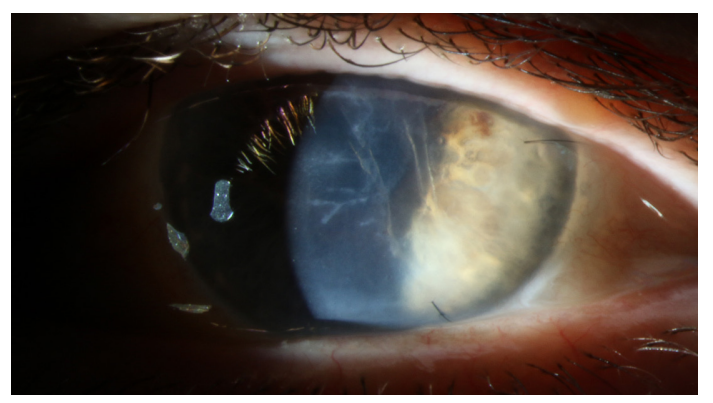

Figure 1 Slit lamp photograph demonstrating the dendritic corneal ulcer overlying an area of Descemet membrane endothelial keratoplasty graft detachment.

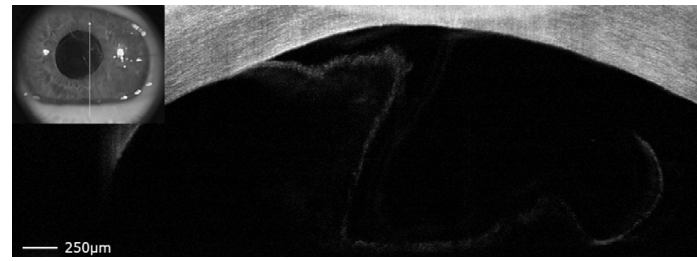

Figure 2 Anterior segment optical coherence tomography image demonstrating Descemet membrane endothelial keratoplasty graft detachment.

6 months postoperatively the uncorrected distance visual acuity was $6 / 12$ in both eyes.

DMEK combined with cataract surgery is the new gold standard for treating Fuchs' endothelial dystrophy with cataract. The benefits over its predecessor, Descemet stripping automated endothelial keratoplasty, are improved visual outcomes and lower graft rejection rates. ${ }^{1}$ Air or sulphur hexafluoride (SF6) gas are most commonly used to facilitate adherence. ${ }^{2}$ In this case there was no history of herpetic eye disease but we are unable to exclude reactivation of latent herpes virus as has been described elsewhere following surgery with or without postoperative topical steroid use. ${ }^{3-5}$ This case highlights an important differential to consider in cases of localised graft detachment. It represents the first report of a dendritic ulcer secondary to HSVK resulting in focal detachment of an endothelial keratoplasty. In such cases it will be necessary to treat the underlying viral infection prior to considering a rebubble or regraft.

\section{Learning points}

A dendritic corneal ulcer, which can be seen with fluorescein staining, is a key diagnostic sign of herpes simplex virus keratitis (HSVK), which is the most common form of ocular HSVK infection and can lead to blindness.

- HSVK can be triggered by ocular surgery and all suspected cases-perioperative or notshould be referred urgently to ophthalmology for assessment and initiation of antiviral treatment. $^{6}$

- Endothelial graft attachment is a key to graft survival following a Descemet membrane endothelial keratoplasty procedure, this case highlights a dendritic ulcer secondary to HSVK as an interesting cause for graft detachment. 
Acknowledgements The authors would like to acknowledge the contribution of Angela Lawler and the imaging staff at BEH in assisting with the production of the figures.

Contributors JC drafted the work and researched the background. ST and KD were involved in the clinical care of the patient and redrafting of the work.

Funding The authors have not declared a specific grant for this research from any funding agency in the public, commercial or not-for-profit sectors.

Competing interests None declared.

Patient consent for publication Obtained.

Provenance and peer review Not commissioned; externally peer reviewed.

\section{ORCID iD}

James Common http://orcid.org/0000-0002-0628-5401

\section{REFERENCES}

1 Deng SX, Lee WB, Hammersmith KM, et al. Descemet membrane endothelial keratoplasty: safety and outcomes: a report by the American Academy of ophthalmology. Ophthalmology 2018;125:295-310.

2 von Marchtaler PV, Weller JM, Kruse FE, et al. Air versus sulfur hexafluoride gas tamponade in Descemet membrane endothelial keratoplasty: a fellow eye comparison. Cornea 2018;37:15-19.

3 Cho YK, Kwon JW, Konda S, et al. Epithelial keratitis after cataract surgery. Cornea 2018;37:755-9.

4 Miyajima S, Sano Y, Sotozono C, et al. [Herpes simplex keratitis after ophthalmic surgery]. Nippon Ganka Gakkai Zasshi 2003;107:538-42.

5 Barequet IS, Wasserzug Y. Herpes simplex keratitis after cataract surgery. Cornea 2007;26:615-7.

6 The National Institute for Health and Care Excellence. Herpes simplex - ocular - NICE CKS [Internet], 2016. Available: https://cks.nice.org.uk/herpes-simplex-ocular\#! !scenario [Accessed 25 Nov 25 2019].

Copyright 2020 BMJ Publishing Group. All rights reserved. For permission to reuse any of this content visit

https://www.bmi.com/company/products-services/rights-and-licensing/permissions/

BMJ Case Report Fellows may re-use this article for personal use and teaching without any further permission.

Become a Fellow of BMJ Case Reports today and you can:

- Submit as many cases as you like

- Enjoy fast sympathetic peer review and rapid publication of accepted articles

- Access all the published articles

Re-use any of the published material for personal use and teaching without further permission

Customer Service

If you have any further queries about your subscription, please contact our customer services team on +44 (0) 2071111105 or via email at support@bmj.com.

Visit casereports.bmj.com for more articles like this and to become a Fellow 